\title{
Protecting Assets for the Most Vulnerable: the Potential for Asset-Based Interventions
}

\author{
Njeri Kagotho ${ }^{1}$
}

Published online: 31 March 2015

(C) Springer International Publishing 2015

\begin{abstract}
In sub-Saharan Africa (SSA), social and economic interactions are governed by both formal (statutory laws, policies, and regulations) and informal institutions (customary laws, social expectations, and religious tenets). When customary and statutory laws misalign, when regressive customary laws are enforced, or when statutory laws are weakly enforced, marginalized groups including children, women, and those impacted by HIV become especially susceptible to economic disenfranchisement predominantly through the misappropriation and loss of household assets. Asset-building interventions working with these groups in the region have shown tremendous success, and whereas they recognize the crucial role formal institutions play in asset accumulation, they are yet to integrate components that address the sociocultural barriers to economic enfranchisement. This paper identifies the ways through which vulnerable groups are susceptible to wealth loss and the ways in which formal and informal rules intersect to restrict property rights. This is followed by an analysis of the informal institutional constraints placed on vulnerable groups in SSA in asset accumulation. Finally, programmatic interventions are proposed that if implemented would increase the capacity of asset-building programs to strengthen the economic functioning of vulnerable groups.
\end{abstract}

Keywords Asset-building · Poverty · Informal institutions · Sub-Saharan Africa

Njeri Kagotho

nkagotho@adelphi.edu

1 Adelphi University School of Social Work, Garden City, NY 11530, USA

\section{Introduction}

Asset-building interventions which facilitate the accumulation of both financial and tangible assets at the individual or household have shown tremendous success in sub-Saharan Africa (SSA) among groups facing multiple vulnerabilities (Chowa et al. 2012; Curley et al. 2010; Johnson et al. 2013; Ssewamala 2005). For these groups - which have included orphaned and vulnerable children (OVC), unemployed youth, women, and households impacted by HIV and AIDS-navigating their way out of poverty is an insurmountable task primarily given their exclusion from institutions that gate-keep much needed resources. Interventions geared towards household economic security in the region have therefore made a conscious effort to circumvent asset-building constraints by facilitating access to these institutions through incentivized savings products, financial literacy, and access to financial intermediaries.

Beverly et al. highlight the crucial role formal institutions play in asset accumulation (2008). They define institutions as purposefully-created policies, programs, products, and services that inform savings behaviors and asset accumulation (Beverly et al. 2008, p. 10). However, in SSA, parameters of interactions and conduct are set within both formal and informal institutional constraints. Informal institutions - which include customary laws - are unwritten patterns of social behavior that are communally enforced and that work in tandem with formal mechanisms. Across the region, customary laws are socially accepted to the extent that some have been enshrined within national constitutions. Given the distinct interplay between formal and informal institutions in SSA, the asset-building process presents a unique set of challenges more so for groups that are forced to navigate both in their attempts at economic security.

Formal institutions such as statutory laws, policies, and regulations are universally applied to all who fall within their 
scope and are slowly changing to align with international laws. Statutory laws are gender neutral and offer protections to the most vulnerable regardless of their social and economic status. Kenya, for example, has in place the Law of Succession Act of 1972 that safeguards the property rights of widow/ers, children, and other dependents. It interfaces with other laws including customary laws to establish a level national platform from which succession is adjudicated (Musyoka 2006). To guarantee social and economic protections and safeguard children against harmful cultural practices, Uganda has in place the national Constitution, the Orphans and Vulnerable Children Policy of 2004, and the Children's Act of 2003 (ANPPCAN-Uganda n.d.; UNICEF \& FIDA Uganda n.d.). Given their complexities, however, accessing the protections accorded by statutory laws can be both cost-prohibitive and difficult to navigate. Customary laws, on the other hand, are community specific and originate from local traditions and religious beliefs. In spite of the heterogeneity across cultures, customary laws do have points of commonalities. These include rigidly defined social hierarchies, subordination of women and children, and discrimination against differently abled individuals.

When customary and statutory laws misalign, when regressive customary laws are enforced, or when statutory laws are weakly enforced, marginalized groups become especially susceptible to economic disenfranchisement. A review of the literature points to documented instances of misappropriation of assets belonging to orphaned children (Csete 2001; Harms et al. 2010; Rose 2007; Wakhweya et al. 2002), widows stripped of wealth after the death of a spouse (Drimie 2003; Korang-Okrah and Haight 2014), grabbing of property belonging to individuals impacted by HIV through violent and nonviolent means (Drimie 2003; Ekin et al. 2009), and women and girls unable to exercise full control over household assets that rightfully belong to them (Ekin et al. 2009; Meinzen-Dick et al. 2007). This juxtaposition of legal and sociocultural rules therefore acts to disenfranchise already vulnerable populations by compounding the difficulties they face in accumulating, securing, and leveraging tangible assets.

As we continue to strengthen the capacity of asset-building interventions in SSA, it is essential to understand the institutional constrains - both formal and informal - that determine household economic security. This is especially salient given that clients enrolled in asset-based interventions cluster around multiple points of vulnerabilities which further undermines their economic capabilities. This paper identifies the ways in which vulnerable groups are susceptible to wealth loss and the ways in which formal and informal rules intersect to limit property rights. The first section provides a brief overview of global asset-building interventions, their genesis, and documented achievements. This is followed by an analysis of the informal institutional constraints placed on vulnerable groups in SSA in asset accumulation. Finally, programmatic interventions aimed at increasing the capacity of assetbuilding programs are proposed.

\section{An Overview of Asset-Building Interventions}

Literature from the last three decades highlights the positive impact asset-building interventions have had in poverty reduction at the individual and household level. Asset-building interventions refer to those programs that facilitate the accumulation of both financial and tangible assets at the individual or household level and which apply an asset-based development theoretical framework (Sherraden 1991). At the core of assetbased interventions is usually an incentivized savings account referred to as an IDA - the individual development account. The IDA allows funders to match a depositor's cash savings, which can then be applied towards the purchase of fixed assets, pay for education, or start a business. ${ }^{1}$ The incentivized savings accounts in and of themselves constitute an "asset"; asset-building programs also incorporate a leveraging component that moves participants beyond cash savings into acquiring fixed and tangible assets.

The inception of IDAs in the early 1990s in the USA is credited with an innovative brand of global economic initiatives whose flexibility is best demonstrated in their ability to adapt and conform to the unique social, political, economic, and cultural features of each host community. IDAs and their subsequent offshoot interventions have taken on an international appeal and expanded into more than ten countries worldwide. In SSA, complete and current asset-based interventions in Uganda, Kenya, and Ghana include the Ugandanbased Assets Africa, SEED-Uganda, Suubi, Suubi-Maka, Bridges to the Future, Suubi + Adherence programs, the YouthSave programs in Kenya and Ghana, and The Impact Assessment Program in Kenya (Chowa et al. 2012; Han et al. 2013; Johnson et al. 2013; Kivumbi 2014; Ssewamala 2005; Ssewamala et al. 2014).

\section{How do Asset-Based Interventions Build and Protect Assets?}

When viewed from a social exclusion perspective, individuals and communities living in poverty are implicitly and explicitly deprived of resources available to others. Especially susceptible are those whose economic instability is predicated not only on financial issues but also on psychological and social factors as well. To remedy these imbalances, asset-building programs

\footnotetext{
${ }^{1}$ Variations of the individual development account exist including youth development accounts (YDA), child development accounts (CDA), and family development accounts (FDA).
} 
create linkages with financial intermediaries while incorporating innovative household level services such as psychosocial supports that target not only participants but also individuals within the family unit.

The relationship between financial well-being and financial intermediaries such as banks is unequivocal (Barr 2004), and therefore linking individuals with financial intermediaries is a key component of asset-based interventions. Individuals who are shut out of financial intermediaries are subject to high financial transaction costs, have limited savings mechanisms, and are exploited by inadequate or predatory credit facilities. World Bank data indicates that in SSA, only $24 \%$ of individuals 15 years and older are banked with the percentage even lower-at $21 \%$ - for women. Additionally, individuals in the lowest $40 \%$ income bracket in SSA report significantly low banking rates $(13 \%)$ second only to individuals in the Middle East and North African region (9\%) (The World Bank 2011).

High banking fees, the absence of banking centers in rural and remote areas, low financial literacy and language hurdles, and the systematic discounting of groups perceived as unprofitable are all factors attributed with making banking the purview of a few in many developing countries (Triki and Faye 2013). Asset-building interventions are steadily eliminating these barriers and have demonstrated capacity at increasing banking rates among the most vulnerable. Pilot data from the YouthSave projects in Kenya and Ghana, which use saving accounts as a mechanism for youth development, indicates that prior to enrollment, only 10 and $4 \%$ of youth in Kenya and Ghana, respectively (Kenya $N=384$, Ghana $N=306$ ), were previously banked (Johnson et al. 2012). Given that the YouthSave Kenya and Ghana programs are projected to enroll a significant number of youth, with more than 16 , 000 opened to date (Johnson et al. 2013), their potential to help youth build wealth from an early age is remarkable. Given their current reach and projected scope, these interventions are addressing a real need among economically disenfranchised youth, children, and people living with HIV (PLHIV) by creating critical connections between these previously underserved groups and financial intermediaries.

Equipping individuals with basic financial literacy skills provides individuals with the tools needed to successfully navigate their economic environment. Existing asymmetries in how information is disseminated disenfranchises those who are already most at risk of being poor. While the curriculum specifics vary across intervention sites, their effectiveness in helping individual assets is evident (Clancy et al. 2001). Asset-based interventions are not only interested in the savings aspect of wealth creation but also recognize that creating a sustainable cash flow is crucial to ensuring the success of any long-term asset-building program. In Uganda, financial management workshops are used to train participating youth and their guardians on locally available income-generating investment options (Ssewamala and Ismayilova 2009). These strategies are showing promising results with Karimli and colleagues reporting that HIV-impacted households currently enrolled in a matched savings accounts program do not divest existing household assets in their efforts to keep up their end of the cash deposits (Karimli et al. 2014). They conclude that families hold on to their current assets while simultaneously sourcing cash deposits from other income-generating ventures (Karimli et al. 2014). Other forms of asset management trainings provide participants with the tools necessary to maintain their assets (Chowa et al. 2012). Equipping participants with the tools needed to maintain a home, run a micro-business, and navigate post-secondary education shore up program participants' capacity to maintain accumulating assets.

In working to strengthen the economic future of vulnerable groups, asset-based interventions also incorporate support mechanisms that socially empower participants. Children with minimal social capital, individuals living in a household impacted by HIV who experience constant stigma and social isolation, and women and girls living in gender oppressive environments face more than financial barriers in their quest for economic security. Because these populations experience social and psychological barriers in addition to financial barriers, additional psychosocial support mechanisms have become a mainstay of these interventions. Individual and family level mechanisms which facilitate information sharing and the exchange of ideas, mentorship, and peer support groups all enable clients to reaffirm their social and individual identities and establish validating social connections. Qualitative data from Bridges to the Future finds that children enrolled in the intervention view the mentorship program - which is provided in tandem with the matched savings account-as vital in helping them achieve the economic goals they set for themselves (Ssewamala et al. 2014).

It is clear therefore that asset-based interventions in and of themselves constitute a well-rounded approach to economic empowerment. By building bridges to financial intermediaries and crafting financial trainings tailored to populations that had once been previously ignored, this group of interventions is making substantial headway in addressing the economic needs of the most vulnerable. In addition, extending services to address psychological issues that plague these groups, while innovative in its own right, has begun to address what were once overlooked barriers to economic well-being. However, in addition to economic barriers, clients of asset-based programs are also faced with sociocultural and legal barriers that impede 
their economic security, factors that remain unaddressed in these programmatic interventions.

\section{Analysis of Asset Retention among the Most Vulnerable}

Environmental constraints make it difficult for individuals to maintain full control over individual and household assets. Asset-building programs in SSA work with households impacted by HIV/AIDS, orphaned and vulnerable children, and women. Characteristics linked to biomedical, social status, gender, and age attributes reinforce barriers that inhibit these groups' access to economic opportunities. For vulnerable populations, sociocultural barriers and the burdensome and complex nature of the legal system act as impediments to accessing the legal infrastructure that governs and determines economic success (Palacio 2006; United Nations 2009). Lowincome individuals often lack the resources needed to legally secure property. Instances of property loss due to fraud, corruption, and exertion of undue family influence have been documented (Kagotho 2014). In the recent past, sub-Saharan nations have continued to reinforce legal infrastructure - in the form of laws, regulations, and legal machinery including judicial and policing systems - in a bid to protect the rights of citizens. In as much as these advancements secure the rights of the most vulnerable, some customary rules continue to create barriers to these protections (United Nations 2009).

\section{Vulnerable Children and Assets}

Intergenerational wealth transfers are closely linked to family economic stability (Bird and Pratt 2004; Kohler et al. 2012; Wilhelm 2001). In instances of intestacy and where customary laws and social dictates decree that family wealth will not automatically devolve to children and wives, these families face the real danger of losing control over household wealth. Moreover, given that cultural taboos still restrict discussions that revolve around death and dying (Daniel et al. 2007; Foster and Williamson 2000), children living in families that experience the death of a significant income provider without advance wealth planning risk a clamorous period of family succession. HIV and other epidemics, labor migration, and economic necessities have led to an increase in the number of vulnerable children living with non-parent carers. In SSA alone, UNICEF places the number of children who have lost one parent (single orphaned) at approximately 54 million and at 8.5 million for double orphaned children (UNICEF 2013). Of all the social conditions that have exerted a negative toll on children's well-being, HIV and AIDS has been one of the hardest hitting and although technological advancements have improved the quality of life of those with a HIV diagnosis, early mortality rates - due to opportunistic infections, poor nutrition, and inaccessible therapies - are still relatively high.

In households impacted by HIV and AIDS, heads of households are the ones infected $75 \%$ of the times. An HIV diagnosis is critical to a family's economic well-being (Belsey 2005; Kagotho 2012; Yamano and Jayne 2004). The household changes that follow inadvertently compromise household functioning. HIV is a resource intensive disease and coupled with the inability to engage in productive labor due to poor health, a household's ability to accumulate assets, exercise control over economic resources is significantly compromised (Carpano et al. 2007; Izumi 2007). Further complicating the issue are the weakening social networks that result from social isolation and stigma associated with the diagnosis (Mbonu et al. 2009). Weakened social connections not only preclude access to certain social resources but also curtail the information conduits necessary to navigate their tenuous circumstances.

In cases of intestacy where families lack the knowledge and access to laws created to protect household assets, where the only institutions accessible are customary laws and social dictates that do not give them preference in asset devolution, children in these families face the real danger of losing control over household wealth. Studies across the continent find that children have become especially vulnerable to wealth misappropriation and property grabbing. Instances of relatives and nonrelatives alike displacing orphaned children from their family home, making away with household goods, and using coercive techniques to exert control over household finances are documented throughout the region (Csete 2001; Drimie 2003; Harms et al. 2010; Kiai et al. 2002; Rose 2007; Satzinger et al. 2012; Wakhweya et al. 2002). Children's vulnerability to wealth loss does not necessarily follow a parent's death. Wrangles over family property are known to begin even before the death of a parent where relatives plot ways through which to disinherit orphans of their parent's property (Harms et al. 2010; Izumi 2006). Even with the explicit protections provided through the legal system, the interaction between customary laws and sociocultural norms and expectations engender a climate enabling of these types of marginalization.

A prime example of this type of situation is Uganda. It recognizes the application of customary laws but nationally prohibits any sections of the same that either exploit or marginalize children. The country has in place several laws that protect the property rights of children - including orphans and children living with disabilities. The Constitution, the Orphans and Vulnerable Children Policy of 2004, the Children's Statute of 1996, and the Children's Act of 2003 all guarantee social and economic protections including protections from harmful cultural practices (ANPPCAN-Uganda n.d.; UNICEF \& FIDA Uganda n.d.). Even with these protections, estimates indicate that approximately $16-35 \%$ of all orphans lose property left to them after a parent's death 
(Caruso and Cope 2006; Wakhweya et al. 2002). When parents die intestate, the children they leave behind are vulnerable to wealth loss because other individuals can and do circumvent the legal system in their favor. Qualitative data collected from six districts in Uganda by Ntozi and Mukiza-Gapere (1995) indicated that in the absence of a will, widows and their orphans were at risk of property loss due to disinheritance after the death of a father/husband by their appointed guardians. Additional cases are recorded where children in foster care are accorded minimal to no input whatsoever in the administration of wealth held in trust for them by relatives (Oleke et al. 2006).

Other points of vulnerability include guardianship relationships which when unregulated no longer protect the rights of vulnerable children and may essentially work against them. Siblings, grandparents, and other relatives have been called upon to provide care to vulnerable children, and often these relationships are not formalized through legal guardianship or adoptions. This lack of formalization likely compromises a family's ability to secure and transfer wealth from one member to another. In addition, when guardians are unable or unwilling to offer children adequate protections, children's economic stability is greatly compromised (Rose 2007).

\section{Women and Assets}

Disenfranchisement of women through loss of property is a recognized social issue and has been extensively documented across sub-Saharan Africa (United Nations 2009). Women's access to wealth is directly related to positive household wellbeing. Denying a woman the right to exercise full control over wealth holdings diminishes her bargaining power within the household and curtails any economic undertakings she may undertake (Meinzen-Dick et al. 2007). However, gender roles and expectations informed by social and cultural norms give rise to practices that disenfranchise women in economic development. In addition to international statutes, gender neutral laws that protect and secure property rights for women are slowly becoming part and parcel of the legal reforms currently taking place on the continent (FIDH and FHRI 2012; KameriMbote 2006; Rose 2007). However, regressive cultural expectations and rigid gender hierarchies continue to disenfranchise women. A review of the literature indicates that in all of subSaharan Africa, countries that currently host asset-building programs also recognize and allow for the application of customary laws. Weak property rights, rights dependent on male relationships, property grabbing, and violence are all barriers faced by women that may not be necessarily addressed by current asset-based programs.

Disinheritance and other forms of property grabbing have become a characteristically gender-based form of violence (Izumi 2007). Property grabbing is the process through which relatives and nonrelatives alike coerce women into giving up rights and control over property that rightfully belongs to them. Throughout the region, instances of women and their children losing household items and fixed assets such as land and houses to grabbing are documented (Drimie 2003; Izumi 2006; KorangOkrah and Haight 2014). Patriarchal systems that favor men, corrupt legal systems, and poverty are several factors cited for property grabbing that faces women. Modern day gender neutral laws and affirmative action tools, on the other hand, attempt to level out the playing field while redressing some of the historical injustices that have seen women excluded from economic opportunities. Because societies consent to the application of both sets of laws, and because these laws are often not harmonized, women face an uphill battle in their efforts to secure assets. A qualitative study conducted in Kenya with both men and women living with a HIV diagnosis found that communities are well aware of the discrepancies posed by the two sets of laws (more so for women and orphaned children), thereby recognizing that cultural laws do inhibit the devolution of family wealth to them (Kagotho 2014).

Women's access to property is sometimes tenuous and tied to her relationship with a male relative (Doss et al. 2012; Kagotho 2014; Oduro et al. 2010; Walsh 2003). This means that a woman's decision to access, leverage, or dispose assets often fall secondary to those of other male householders. In such instances, individual property rights are not always equivalent to full property rights meaning that one may not necessarily have the right to leverage or dispose of assets as one wills. Death, divorce, or a souring relationship with a male family member can have adverse effects on a woman's ability to make autonomous economic decisions. When a woman's ability to own and fully control assets is conditioned on her relationship to a male relative, her ability to fully maximize the utility of these assets is greatly curtailed (Meinzen-Dick et al. 2007; Walsh 2003). The misalignment between women's economic potential and the assets they have direct control over also means that women inherently face more obstacles in exerting control over wealth when compared to men. In addition, women are sometimes unable to exercise full rights over their property including the ability to leverage assets as collateral due to economic violence. Economic violence manifest as strained family relations, intimidation and physical violence resulting from attempts to secure assets are recorded (Vyas and Watts 2009). To mitigate these challenges, women may temper their own efforts at asset accumulation or relinquish their rights at making decisions over those assets that they rightfully possess (Oduro et al. 2010). Therefore, even in instances where national laws, policies, and regulations guarantee women the ability to fully participate in economic activities, constraints placed upon them by social expectations restrict what they are capable of. 


\section{Current Programmatic Interventions}

Asset-based interventions are making substantial strides in building and shoring up the economic foundation for different vulnerable groups in SSA. This paper has sought to elucidate how the asset-building field facilitates economic security for these groups by working alongside formal institutions such as banks, schools, and community-based organizations. These services, provided to individuals and the communities they reside in, help propel participants towards their economic goals. However, this paper also demonstrates that the groups enrolled in asset-based interventions are also those most likely to face barriers to long-term economic security through disinheritance, property grabbing and asset misappropriation factors that occur through informal institutions including unwritten customary laws. Asset-based programs' successes at understanding and working within local milieus makes them well placed to integrate the mechanisms that enable communities transcend the sociocultural barriers to long-term assets retention. The trust cultivated with vulnerable individuals and groups, the reach and goodwill enjoyed with the communities within which they work, and their ability to work across professional fields are fundamental characteristics that would enable these interventions to institute protective measures for assets accumulated by program participants.

Community programs across the continent have made attempts at securing the wealth of vulnerable groups, and these provide a blueprint from which asset-based interventions could build upon. These programmatic interventions include: (a) age-appropriate legal education to children; (b) sensitizing communities on the association between secure property rights and community economic security; (c) providing vulnerable individuals with connections to legal services such as paralegal services; and finally (d) encouraging and guiding families in succession planning through strategies like will writing.

Children who have had firsthand personal experiences with property grabbing after the death of one or both parents have cited lack of clear legal information as a barrier to securing household assets for themselves and their siblings (Izumi 2006; Rose 2007). Eliminating information asymmetries associated with the legal framework could provide OVC with a better chance at protecting and holding on to household assets in the long term. Asset-based interventions currently offer financial literacy modules to children and youth enrolled in those programs. Incorporating basic legal information as part of this educational component could be a next step for these interventions. Integrating basic legal information would in effect empower children and young adults to secure the assets they build and hold on to those left behind after the death of a parent or a caregiver.

Connecting communities to the legal resources, they need to enable them to secure wealth that rightfully belongs to them fits well within the mandate of asset-building programs. And the fact that asset-based interventions are exceptionally well versed at working across the professions heightens their ability to initiate partnerships with local law professionals. Several community initiatives in the region do train and connect local communities to paralegal services, including the Child Social Care Project in Uganda. The Rakai Child Social Care Project (CSCP) whose major primary focus is the protection of wealth belonging to widows and orphans impacted by HIV reports various mechanisms to achieve their goals (Witter et al. 2004), one of which is the training of paralegals. The legal information dispensed enables paralegals to provide assistance to children facing loss of property after the death of a parent(s). In addition to helping communities interpret and understand their rights as guaranteed by statutory law, these legal assistants are also charged with facilitating connections between community members and legal resources. The training of paralegals is an effective approach. It provides families with the tools needed to plan for succession and to ensure that accumulated wealth is adequately protected. Other community-based programs that connect communities to legal services include the Grassroots Organizations Operating Together in Sisterhood (GROOTS) in Kenya, and Law and Development Association (LADA) in Zambia (Betancur et al. n.d.; GROOTS Kenya n.d.; ICRW 2006). The documented success of asset-based interventions means that they enjoy a substantial amount of goodwill in the communities they work in. Given their good standing, initiating community level sensitization information sessions on the rights of vulnerable populations could be another point of intervention. Involving local communities in the adjudication of wealth disputes is nothing new as several community programs in SSA do have community sensitization interventions to address issues related to property right violations among widows and orphans with documented successes (GROOTS 2013; Izumi 2006; Roys 1995; Witter et al. 2004). GROOTS Kenya trains and dispatches volunteer groups consisting of 12-20 individuals trained to resolve reported property grabbing cases that relate to women. By sensitizing and educating community leaders and members, these volunteer groups have had documented success in protecting wealth belonging to widows and children in Kenya (GROOTS 2013).

The importance of educating communities on will writing as a means of safeguarding family property (Izumi 2007; Ntozi and Mukiza-Gapere 1995) has been discussed at length in the literature. As social norms and expectations place constrains on discussions of mortality, demystifying the will writing process for vulnerable households would ensure a smooth succession of family wealth and help protect the property rights of the most vulnerable. In Uganda, the National Community of Women Living with AIDS (NACWOLA) memory project has used memory books as a tool to 
encourage families dealing with HIV to openly discuss issues related to the diagnosis while providing them with the tools needed to engage in succession planning including will writing (Witter and Were 2004). A memory book is a written family record designed to foster inter-generational communication by providing family members with a forum via which to record genealogical information, memories, and future aspirations. In the case of NACWOLA, memory books were additionally designed to include a listing of family assets and a will to ensure that children retained control over these after the death of a parent/caregiver (Witter and Were 2004). Because some asset-based programs already provide support services at the family level, integrating a component to encourage listing of all household assets, allowing parents to appoint carers, and will writing as an approach to securing household assets in the long run.

\section{Conclusion}

Asset-building interventions aim to build sustainable wealth by working alongside households that are in the process of acquiring and accumulating assets. Client groups likely to participate in asset-based programs are also those most likely to experience difficulties in accumulating, retaining control of, and leveraging assets due to a confluence of economic, sociocultural, and legal factors. As these interventions expand into more countries in SSA, increasing our knowledge of how vulnerable populations navigate the environment engendered by both formal and informal institutions will equip them to provide better services.

Asset-building interventions have managed to successfully address financial barriers to economic security - by brokering access to financial intermediaries, providing financial literacy, and income-generating opportunities - but there remains the need to simultaneously facilitate access to sociocultural and legal institutions charged with protecting accumulated assets. Historically, customary law has provided for the protection of vulnerable groups including the chronically ill, orphaned children, and widows. The changing social and economic environment-including exacerbated poverty rates, increasing caregiving burden, and changing social mores - has left this demographic especially susceptible to wealth mismanagement. Statutory laws on the other hand which are now for the most part progressive - gender neutral and protective of children and other vulnerable groups - are either inaccessible or weakly enforced, further diminishing individual's capacity to fully engage their environment in a way that allows them to maximize their well-being. The next steps in asset accumulation strategies would be to ensure that clients retain full access and control over these assets long after the conclusion of their participation within these programs.
The complex nature of poverty means that realistically no single intervention could ever adequately address all the nuances of this phenomenon. The versatility of asset-based programs, however, makes them well suited to extend their reach beyond just the financial factors into the sociocultural and legal antecedents of poverty. As this article has shown, asset-based programs are advantageously placed to integrate these mechanisms given the goodwill they have established with local communities, their ability to work with and across professions, and most importantly, their mandate to help vulnerable individuals and households strengthen economic functioning.

\section{References}

ANPPCAN-Uganda. (n.d.). Childrights and protection: the legal framework. http://www.anppcanug.org/wp-content/uploads/press kits/ Legal_Frawrk_of_child_protection.pdf. Accessed 3 Sep 2014.

Barr, M. S. (2004). Banking the poor. Yale Journal on Regulation, 21(1), $123-237$.

Belsey, M. (2005). AIDS and the family. Policy options for a crisis in family capital. New York: U.N.

Betancur, M. L., Dadzie, C., Jagannath, M., Majeed, R., Shibatsuchi, M., \& Waters, E. (n.d.). Law and development association of the southern province of Zambia. An assessment of the adult paralegal program. NY, NY: Columbia University School of International and Public Affairs.

Beverly, S., Sherraden, M., Zhan, M., Williams Shanks, T., Nam, Y., \& Cramer, R. (2008). Determinants of asset building. Urban Institute Poor Finances Series. Washington, DC: The Urban Institute.

Bird, K., \& Pratt, N. (2004). Fracture points in social policies for chronic poverty reduction. CPRC Working Paper 47.

Carpano, F., Izumi, K., \& Mathieson, K. (2007). Gender, property rights and livelihoods in the era of AIDS FAO Technical Consultation. Rome, Italy: FAO.

Caruso, J., \& Cope, K. (2006). The lost generation: how the government and non-governmental organizations are protecting the rights of orphans in Uganda. Human Rights Review, 7(2), 98-114.

Chowa, G., Masa, R. D., \& Sherraden, M. (2012). Wealth effects of an asset-building intervention among rural households in sub-Saharan Africa. Journal of the Society for Social Work and Research, 3(4), 329-345.

Clancy, M., Grinstein-Weiss, M., \& Schreiner, M. (2001). Financial education and savings outcomes in individual development accounts: Working Paper 01-2. St. Louis, MO: Center for Social Development, Washington University.

Csete, J. (2001). In the shadow of death: HIV/AIDS and children's rights in Kenya. Human Rights Watch, 13(4(A)), 1-35.

Curley, J., Ssewamala, F. M., \& Han, C.-K. (2010). Assets and educational outcomes: Child Development Accounts (CDAs) for orphaned children in Uganda. Children and Youth Services Review, 32(11), 1585-1590.

Daniel, M., Apila, H. M., Bjørgo, R., \& Lie, G. T. (2007). Breaching cultural silence: enhancing resilience among Ugandan orphans. African Journal of AIDS Research, 6(2), 109-120.

Doss, C., Truong, M., Nabanoga, G., \& Namaalwa, J. (2012). Women, marriage and asset inheritance in Uganda. Development Policy Review, 30(5), 597-616.

Drimie, S. (2003). HIV/AIDS and land: case studies from Kenya, Lesotho and South Africa. Development Southern Africa, 20(5), 647-658. 
Ekin, T. K., Lumumba, O., \& Wamalwa, B. (2009). Land tenure and property rights assessment: agricultural enterprise initiatives of USAID/Kenya Nairobi, Kenya: USAID.

FIDH, FIDA-U, \& FHRI. (2012). Women's rights in Uganda: gaps between policy and practice. Retrieved September 6, 2014, from Foundation for Human Rights Initiative http://www.fidh.org.

Foster, G., \& Williamson, J. (2000). A review of current literature on the impact of HIV/AIDS on children in sub-Saharan Africa. AIDS, 14(Suppl 3), 275-284.

GROOTS Kenya. (2013). GROOTS Kenya. Retrieved October 6, 2014, from http://www.grootskenya.org.

GROOTS Kenya. (n.d.). Policy brief: the complementary role of community land and property watchdog groups in protecting women's land rights in Kenya. http://web.idrc.ca/uploads/user-S/ 12850770631GROOTS_Kenya_Policy_Brief_Complementary_ Role_of_WDGs1.pdf. Accessed 6 Oct 2014.

Han, C.-K., Ssewamala, F. M., \& Wang, J. S.-H. (2013). Family economic empowerment and mental health among AIDS-affected children living in AIDS-impacted communities: evidence from a randomised evaluation in southwestern Uganda. Journal of Epidemiology and Community Health, 67(3), 225-230.

Harms, S., Jack, S., Ssebunnya, J., \& Kizza, R. (2010). The orphaning experience: descriptions from Ugandan youth who have lost parents to HIV/ AIDS. Child and adolescent psychiatry and mental health, 4(6), 1-10.

ICRW. (2006). Reducing women's and girls' vulnerability to HIV/AIDS by strengthening their property and inheritance rights. Retrieved October 6, $2014 \mathrm{http} / / /$ data.unaids.org.

Izumi, K. (Ed.). (2006). Report of the regional workshop on HIV and AIDS and children's property rights and livelihoods in Southern and East Africa. Harare, Zimbabwe: FAOSAFR.

Izumi, K. (2007). Gender-based violence and property grabbing in Africa: a denial of women's liberty and security. Gender \& Development, 15(1), 11-23.

Johnson, L., Lee, Y., Osei-Akoto, I., Njenga, M., \& Sharma, S. (2012). Product pilot report: Youth savings performance in Ghana, Kenya, and Nepal (YouthSave Research Brief 12-38). Washington University, Center for Social Development, St. Louis, MO.

Johnson, L., Lee, Y. S., Sherraden, M., Chowa, G., Ansong, D., Ssewamala, F., . . . Saavedra, J. (2013). Savings patterns and performance in Colombia, Ghana, Kenya, and Nepal (YouthSave Research Report). St. Louis, MO: Washington University, Center for Social Development.

Kagotho, N. (2012). A future of possibilities: educating children living in HIV impacted households. International Journal of Educational Development, 32(3), 394-400.

Kagotho, N. (2014). Inheritance in Kenya: the intersectionality of HIV sero-status, poverty, and gender. AFFILIA: Journal of Women and Social Work. doi:10.1177/0886109914528699.

Kameri-Mbote, P. (2006). Women, land rights and the environment: the Kenyan experience. Development, 49(3), 43-48.

Karimli, L., Ssewamala, F., \& Neilands, T. B. (2014). Poor families striving to save in matched children's savings accounts: findings from a randomized experimental design in Uganda. The Social Service Review, 88(4), 658-694.

Kiai, W., Mwangi, W., \& Bosire, E. (2002). The impact of HIV/AIDS on the land issue in Kenya. Nairobi: Forest Action Network.

Kivumbi, A. (2014). Youth adherence to ART in Sub-Saharan Africa: the Suubi + Adherence Study Paper presented at the Global Perspectives on Adolescent Health and Economic Strengthening Conference, Chicago, IL.

Kohler, I. V., Kohler, H.-P., Anglewicz, P., \& Behrman, J. R. (2012). Intergenerational transfers in the era of HIV/AIDS: evidence from rural Malawi. Demographic Research, 27(27), 775-834.

Korang-Okrah, R., \& Haight, W. (2014). Ghanaian (Akan) women's experiences of widowhood and property rights violations: an ethnographic inquiry. Qualitative Social Work. doi:10.1177/ 1473325014526275 .
Mbonu, N. C., van den Borne, B., \& De Vries, N. K. (2009). Stigma of people with HIV/AIDS in Sub-Saharan Africa: a literature review. Journal of Tropical Medicine, 2009(145891), 14. doi:10.1155/2009/ 145891.

Meinzen-Dick, R., Kameri-Mbote, P., \& Markelova, H. (2007). Property rights for poverty reduction 2020 focus brief on the world's poor and hungry people. Washington, DC: IFPRI.

Musyoka, W. M. (2006). Law of succession. Nairobi: LawAfrica Publishing (K) Ltd.

Ntozi, J. P., \& Mukiza-Gapere, J. (1995). Care for AIDS orphans in Uganda: findings from focus group discussions. Health Transition Review, 5, 245-252.

Oduro, A. D., Baah-Boateng, W., \& Boakye-Yiadom, L. (2010). Asset Accumulation by Women in Ghana: understanding the Process The Gender Asset Gap Project. Working Paper Series: No. 4. Karnataka, India: Indian Institute of Management Bangalore.

Oleke, C., Blystad, A., Moland, K. M., Rekdal, O. B., \& Heggenhougen, K. (2006). The varying vulnerability of African orphans: the case of the Langi, northern Uganda. Childhood, 13(2), 267-284.

Palacio, A. (2006). Legal empowerment of the poor: an action agenda for the World Bank: World Bank.

Rose, L. (2007). Children's property and inheritance rights, HIV and AIDS, and social protection in Southern and Eastern Africa. HIV/ AIDS Programme Working Paper 2. Food and Agriculture Organization.

Roys, C. (1995). Widows' and orphans' property disputes: the impact of AIDS in Rakai district Uganda. Development in Practice, 5, 346351.

Satzinger, F., Kipp, W., \& Rubaale, T. (2012). Ugandan HIV/AIDS orphans in charge of their households speak out: a study of their health-related worries. Global Public Health, 7(4), 420-431.

Sherraden, M. (1991). Assets and the poor: A new American Welfare Policy. New York: ME Sharpe Inc.

Ssewamala, F. (2005). Children development accounts in Africa: a pilot study (CSD Research Report 05-36). St. Louis, MO.

Ssewamala, F., \& Ismayilova, L. (2009). Integrating children's savings accounts in the care and support of orphaned adolescents in rural Uganda. Social Service Review, 83(3), 453.

Ssewamala, F., Nabunya, P., Mukasa, N. M., Ilic, V., \& Nattabi, J. (2014). Integrating a mentorship component in programming for care and support of AIDS-orphaned and vulnerable children: lessons from the Suubi and Bridges programs in sub-Saharan Africa. Global Social Welfare, 1(1), 9-24.

The World Bank. (2011). Financial inclusion data. Retrieved September 14, 2014, from http://datatopics.worldbank.org.

Triki, T., \& Faye, I. (Eds.). (2013). Financial Inclusion in Africa. Tunisia: African Development Bank.

UNICEF. (2013). Orphan estimates. Retrieved May 7, 2014 http:// www.childinfo.org.

UNICEF, \& FIDA Uganda. (n.d). Collection of children laws. A simplified hand book on international and national laws \& policies on children Retrieved September 3, 2014 http://www.unicef.org

United Nations. (2009). Legal empowerment of the poor and eradication of poverty. Report of the Secretary General. New York: United Nations.

Vyas, S., \& Watts, C. (2009). How does economic empowerment affect women's risk of intimate partner violence in low and middle income countries? A systematic review of published evidence. Journal of International Development, 21(5), 577-602.

Wakhweya, A., Kateregga, C., Konde-Lule, J., Sabin, L., Williams, M., \& Heggenhougen, K. (2002). Situation analysis of orphans in Uganda: Orphans and their households: Caring for the future today: The Government of Uganda and Uganda AIDS Commission.

Walsh, J. (2003). Double standards: women's property rights violations in Kenya. Human Rights Watch, 15(5.A), 1-51. 
Wilhelm, M. O. (2001). The role of intergenerational transfers in spreading asset ownership. In M. F. Shapiro \& E. N. Wolff (Eds.), Assets for the Poor. The benefits of spreading asset ownership. New York: Russell Sage.

Witter, S., \& Were, B. (2004). Breaking the silence: using memory books as a counselling and succession-planning tool with AIDS-affected households in Uganda. African Journal of AIDS Research, 3(2), 139-143.
Witter, S., Ahimbisibwe, T., \& Calder, G. (2004). Taking better care: Review of a decade of work with orphans and vulnerable children in Rakai. Uganda: Save the Children Fund.

Yamano, T., \& Jayne, T. S. (2004). Measuring the impacts of working-age adult mortality on small-scale farm households in Kenya. World Development, 32(1), 91-119. 